\title{
Interfacing DNA with Gold Nanoparticles for Heavy Metal Detection
}

\author{
Zhiyu He ${ }^{1, \dagger}$, Huiling Yin ${ }^{1, \dagger}$, Chia-Chen Chang ${ }^{3,4}\left(\mathbb{D}\right.$, Guoqing Wang ${ }^{1,2, *} \mathbb{D}$ \\ and Xingguo Liang ${ }^{1,2} \mathbb{D}$ \\ 1 College of Food Science and Engineering, Ocean University of China, Qingdao 266003, China; \\ hezhiyu@stu.ouc.edu.cn (Z.H.); yinhuiling@stu.ouc.edu.cn (H.Y.); liangxg@ouc.edu.cn (X.L.) \\ 2 Laboratory for Marine Drugs and Bioproducts, Pilot National Laboratory for Marine Science and \\ Technology (Qingdao), Qingdao 266237, China \\ 3 Department of Medical Biotechnology and Laboratory Sciences, College of Medicine, \\ Chang Gung University, Taoyuan 33302, Taiwan; chang@mail.cgu.edu.tw \\ 4 Kidney Research Center, Department of Nephrology, Chang Gung Memorial Hospital, \\ Taoyuan 33302, Taiwan \\ * Correspondence: gqwang@ouc.edu.cn \\ + These authors contributed equally to this work.
}

Received: 9 October 2020; Accepted: 4 November 2020; Published: 6 November 2020

\begin{abstract}
The contamination of heavy metals (e.g., $\mathrm{Hg}, \mathrm{Pb}, \mathrm{Cd}$ and $\mathrm{As}$ ) poses great risks to the environment and human health. Rapid and simple detection of heavy metals of considerable toxicity in low concentration levels is an important task in biological and environmental analysis. Among the many convenient detection methods for heavy metals, DNA-inspired gold nanoparticles (DNA-AuNPs) have become a well-established approach, in which assembly/disassembly of AuNPs is used for colorimetric signaling of the recognition event between DNA and target heavy metals at the AuNP interface. This review focuses on the recent efforts of employing DNA to manipulate the interfacial properties of AuNPs, as well as the major advances in the colorimetric detection of heavy metals. Beginning with the introduction of the fundamental aspects of DNA and AuNPs, three main strategies of constructing DNA-AuNPs with DNA binding-responsive interface are discussed, namely, crosslinking, electrostatic interaction and base pair stacking. Then, recent achievements in colorimetric biosensing of heavy metals based on manipulation of the interface of DNA-AuNPs are surveyed and compared. Finally, perspectives on challenges and opportunities for future research in this field are provided.
\end{abstract}

Keywords: biosensing; DNA; gold nanoparticles; interface; heavy metal

\section{Introduction}

Environment and food contamination by heavy metals and the resulting adverse effects to the ecosystem and human health have been issues of increasing concern worldwide [1]. Particularly, mercury $(\mathrm{Hg})$, lead $(\mathrm{Pb})$, cadmium $(\mathrm{Cd})$ and arsenic (As) are widespread toxic pollutants [2], among which arsenic as a metalloid is often classified as a heavy metal in terms of its similar contamination sources and molecular mechanisms of toxicity as compared to other heavy metals [3]. It is worth noting that all of the four heavy metals appear in the top 10 chemicals of major public health listed by the World Health Organization (WHO) [4]. By forming stable complexes with essential proteins or enzymes, the heavy metals can interfere with their biological functions in metabolism and antioxidant protection, thereby inducing toxicological and carcinogenic effects on tissues and organs $[1,5,6]$. Since each of the heavy metals, even in small quantities, may cause potent human health effects that depend on the heavy metal's oxidation state and solubility $[7,8]$, many countries and 
international organizations have accordingly defined maximum allowable levels of heavy metals in food, drinking water and other mediums [9]. On the other hand, simple and sensitive testing of heavy metals has become important in environmental analysis, food analysis and medical diagnosis [10].

The innovation of biosensing tools boosted by the development of bionanotechnology provides new avenues to convenient heavy metal detection. As an emerging class of recognition elements, functional DNAs, such as aptamer and DNAzyme, have been screened by combinational biotechnological process, where magnetic beads are often employed to extract and enrich DNA-target complexes magnetically [11-13]. Aptamers are known as DNA or RNA sequences that can specifically bind with molecules or proteins, while DNAzymes are a class of DNA capable of catalyzing reactions (e.g., RNA cleavage); in many cases, using metal ions as cofactors [14]. Both functional DNAs offer high selectivity to the target, and have been utilized for the detection of toxic heavy metals in optical [15] and electrochemical [6] biosensing. On the other hand, gold nanoparticles (AuNPs), which exhibit localized surface plasmon resonance (LSPR), represent an advantageous signal transducer for recognition behaviors over other indicators [16], such as dyes [17], metal oxides [18], coordination complexes [18], polymers [18-20] and enzymes [21], due to the high extinction coefficient, stability and biocompatibility [22,23]. AuNPs can further have their plasmon coupled when they are brought into close proximity, promising distance-dependent optical properties. Based on the combined use of functional DNAs and AuNPs, accordingly, a platform for colorimetric biosensing of heavy metals has become established [24,25]. In comparison to other functional DNA-based sensing strategies, such as electrochemical [6] and fluorescent [26] methods, colorimetric biosensing using DNA-AuNPs offers the benefits of convenience, intuitiveness and elimination of instruments, which are desirable for field analysis.

The responsiveness of interfacial property of DNA-AuNPs to a target is the key to make the biosensor work [27]. The recognition events of the functional DNA to heavy metal species involved at the interface of AuNPs is the major driving force for a responsive interfacial property of DNA-AuNPs, and thereby controls the assembly of DNA-AuNPs $[27,28]$. It has been accepted that, by binding with heavy metal species, aptamers and DNAzymes undergo changes in their confirmation and base pairing status [29]. These events often greatly alter the interfacial interactions among the DNA-AuNPs, thereby triggering the assembly/disassembly of the DNA-AuNPs for signifying the target heavy metal species (Figure 1). The fine design of the characteristic parameters of DNA-AuNPs, including the DNA sequences and the morphology of AuNPs, is the core content of building such DNA-AuNP colorimetric biosensors.

This review focuses on the major advances in heavy metal detection based on DNA-AuNPs, with an emphasis on how DNA integrate with AuNPs to form a sensing platform. This paper starts with a brief introduction of the fundamental aspects of DNA and AuNPs; the mechanisms of DNA recognition-induced interfacial assembly of AuNPs based on crosslinking, electrostatic interaction or base pair stacking will be classified and discussed. Then, methods for colorimetric detection of the widespread toxic heavy metals based on the above mechanisms are surveyed in detail, including $\mathrm{Hg}$, $\mathrm{Pb}, \mathrm{Cd}$ and As. Finally, conclusions on the recent progress and perspectives for future research trends are made, to provide useful information for researchers who work in related fields and to address the challenges for DNA-AuNPs to be applied in detecting a wide range of heavy metals. 


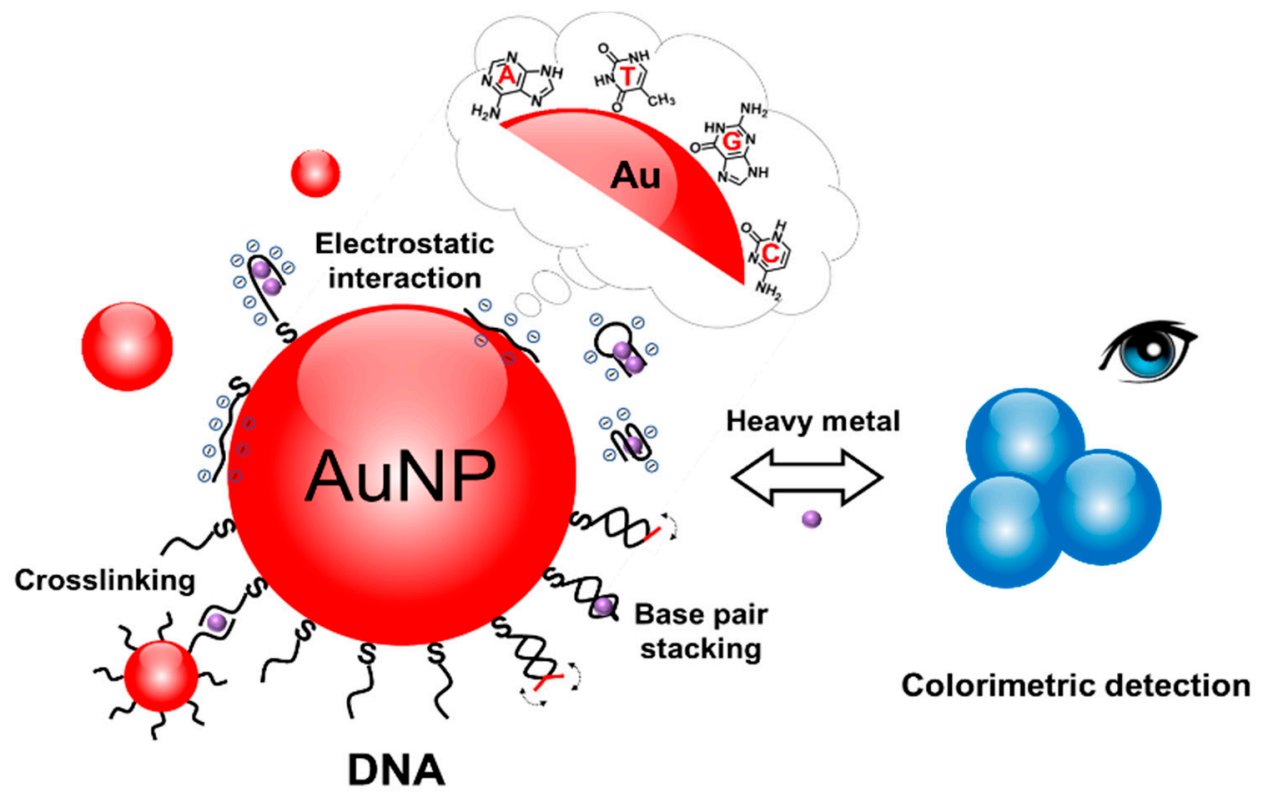

Figure 1. Schematic illustration of surface engineering of gold nanoparticles (AuNPs) with heavy metal-specific DNA.

\section{The Mechanism of DNA-AuNPs' Interfacial Assembly for Heavy Metal Detection}

The conformational change caused by the interaction with heavy metals accounts for the recognition behavior of functional DNA [29]. For example, DNAzymes can be catalyzed to cleave on the deoxynucleotide site with the assistance of metal ions [30], while aptamers can be folded to a secondary structure by binding to heavy metals with specific bases [31]. In addition, thymine and cytosine can be mismatched with the same base as themselves, by forming stable $\mathrm{T}-\mathrm{Hg}{ }^{\mathrm{II}}-\mathrm{T}$ or $\mathrm{C}-\mathrm{Ag}^{\mathrm{I}}-\mathrm{C}$ complexes [32,33].

For effectively manipulating the interface of colloidal AuNPs with the recognition behavior of functional DNA, the fashion of integration between DNA and AuNPs should be considered first [34,35]. In particular, the sequence, length, label and concentration of DNA are key factors that can affect the density and conformation of DNA on a given AuNP. Additionally, there is no doubt that the charge, curvature and surfactant of the AuNP surface play essential roles in determining the manner of integration between DNA and AuNPs [36-38]. Although the many characteristics of DNA and AuNPs make their interactions complicated, researchers did develop reliable methods to characterize and control them [39-43].

\subsection{Fundamental Aspects of AuNPs and DNA}

AuNPs are nanostructured gold consisting of at least thousands of atoms. Dispersed in aqueous solution, AuNPs are in general isolated from each other. The interparticle distance is nearly a thousand of nanometers, which is much larger than their diameter. The strong LSPR effect makes their plasmon band fall in visible regions, appearing in a brilliant reddish or bluish color in a colloidal state that is dependent on their morphologies [23,44]. Spherical AuNPs synthesized by citrate-assisted thermal reduction of $\mathrm{HAuCl}_{4}$ are among the mostly adopted nanostructures [45]. The capping agent determines the surface charge of the AuNPs to be negative [42]. For gold nanorods and nanoplates prepared using cetyltrimethylammonium (CTA) halide [46,47], their surfaces are positively charged. Furthermore, their surface activity is site-dependent due to the structural anisotropy, which has implications in region-selective modification and deposition of species of interest [48-51].

The structural fundamentals endow DNA withcomplex chemical functionalities, and thus are the cause of the smart characteristics of DNA molecules discovered in both biological and non-biological science [52]. Owing to the linear structure consisting of four types of nucleobases (A, G, C, T) that are 
linked by sugar-phosphate backbone, as well as the ease of chemical modification, DNA can integrate with gold surfaces via physicochemical adsorption or covalent binding.

\subsubsection{Adsorption of DNA onto AuNPs}

Although the negatively charged AuNPs capped by citrate are repulsive to the polyanionic DNA backbones, attraction interactions exist and enable the adsorption of unmodified DNA oligonucleotides onto negatively charged AuNPs [53]. Related research has shown that DNA bases have stable coordination interactions with AuNPs via ring nitrogen, exocyclic amino or keto groups in the purine or pyrimidine rings [41], with the binding strength dependent on their chemical structure [54,55]. Adenine possesses the highest binding affinity to AuNPs [56]. It binds with the surface of AuNPs via the exocyclic amino group and the N7 atom [41]. Secondary to adenine, guanine and cytosine interact with AuNPs via the keto group and the neighboring nitrogen [55]. Thymine shows the weakest adsorption to the negatively charged AuNPs, with a possible interaction site through a keto oxygen atom only [41]. The adsorption and desorption of DNA on the surface of AuNP can be controlled by the conformational change of DNA, altering the surface charge of AuNPs.

\subsubsection{Covalent Binding}

Thiol-tagged DNA can bind with AuNPs covalently through the formation of Au-S bound. This innovative configuration of DNA-AuNPs was pioneered by Mirkin et al. Alivisatos et al. have enabled a great deal of applications [57,58]. With the single-point attachment on AuNPs, DNA molecules protrude into solution, providing more opportunities for engineering the interface of DNA-AuNPs in a three-dimensional space for colorimetric determination of heavy metals. When DNA is grafted on AuNPs in a relatively low density, a variety of recognition events are facilitated, including DNA hybridization and target binding [59]. Based on improved methods for surface DNA modification, such as salt-aging [39,60], lowering $\mathrm{pH}[61,62]$ and freezing $[62,63]$, the surface of AuNP can be further encapsulated by a radiative and dense single-stranded (ss) DNA monolayer. The high density of DNA brings great electrostatic repulsion and steric hindrance to the particle surfaces, endowing AuNPs with a good colloidal stability, even in a high-salt environment [22]. In this case, the entropic repulsion reveals its control over the assembly of AuNPs, which is relevant to the mobility of DNA that grafted on AuNPs.

\subsection{Heavy Metal-Responsive Interface of DNA-AuNPs}

Once DNA is integrated with AuNPs, the design of the interface among DNA-AuNPs will be crucial for a sensitive response to target heavy metals [64]. For the controlled interfacial assembly of DNA-AuNPs, connecting neighboring DNA-AuNPs by a heavy metal-enabled DNA base pairing has been one of the well-recognized strategies [57]. Accompanied with a red-to-purple color shift, the interparticle distance among the crosslinked DNA-AuNPs may be predicted or simulated based on the design of the DNA sequence $[65,66]$. This method is thought to be considerably sensitive, since in principle just one ssDNA crosslinker can connect two DNA-AuNPs and sufficiently shorten the interparticle distance [67].

The dispersion of DNA-AuNPs in a colloidal solution usually relies on the electrostatic repulsion among them [68]. The charge distribution of DNA is an essential factor that may influence the colloidal stability of DNA-AuNPs, which may be altered by heavy metal binding. This electrostatics-mediated assembly of DNA-AuNPs for heavy metal detection can be based on either adsorbed [53,69] DNA or covalently grafted [70] DNA on AuNPs.

If it has a high salt concentration, the surface charge of grafted DNA can be screened [71]. The entropy of DNA-AuNPs that is proportional to the flexibility of the grafted DNA becomes decisive in driving the interfacial assembly of DNA-AuNPs. For instance, the entropic repulsion among AuNPs grafted with dense double-strand (ds) DNA can be controlled through terminal DNA base pairing, which was discovered by Maeda and coworkers [72]. When the outermost DNA base pairs are 
mismatched, the AuNPs remain dispersed even at high ionic strength, due to the increased entropic repulsion caused by the fraying motion of unpaired bases [73]. When the dsDNA is fully matched, however, base pairing can restrict the flexibility of the DNA terminals and lead to hydrophobic interaction among the DNA-AuNPs [74,75], thereby inducing the assembly of the dsDNA-AuNPs. It has been established that the status of a single base pairing controlled by the heavy metal-mediated mismatch can cause assembly/disassembly of the dsDNA-AuNPs, which suggest a good potential sensitive colorimetric detection [76,77].

\section{Applications of DNA-AuNPs to Heavy Metal Detection}

In a sensor based on colloidal DNA-AuNP, AuNP is the color indicator, whereas surface DNA molecules are responsible for the recognition of a heavy metal target. The interface of DNA-AuNPs represents a wide space for the binding events. Depending on the design of the sensor, the binding between DNA and the target can either crosslink DNA-AuNPs or trigger great change in the interfacial charge and entropic properties of DNA-AuNPs. The binding-induced interfacial assembly/disassembly of DNA-AuNPs for the sensing of heavy metals will be discussed.

\subsection{Target-Driven Crosslinking of DNA-AuNPs}

Among the various strategies for colorimetric detection of analytes using DNA-AuNPs, crosslinking assembly of DNA-AuNPs induced by target binding is the most straightforward (Figure 2a) [78]. In a crosslinking-based detection scheme, neighboring DNA-AuNPs are brought into close proximity via target binding, which thereby form sandwich configurations that induce a color shift from red to blue. Over the past two decades, this methodology has been developed for the detection of various $\mathrm{Hg}$ species and $\mathrm{Pb}^{2+}$ at low concentration levels [79].

(a)

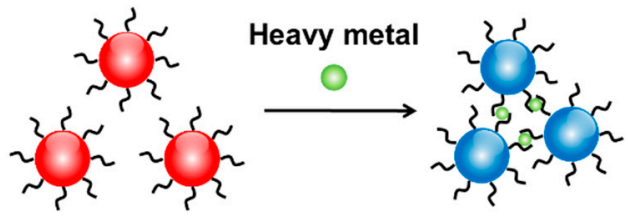

(c)

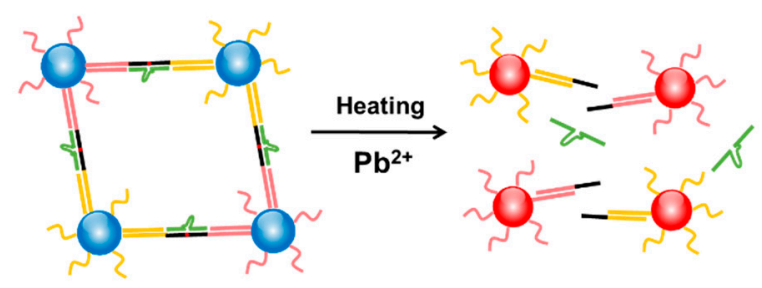

(b)

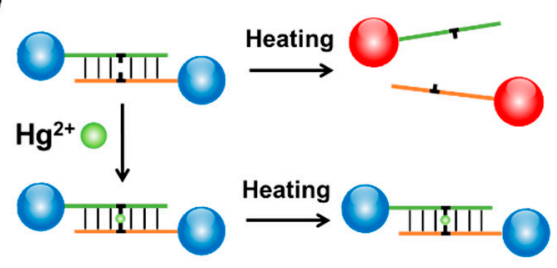

(d)

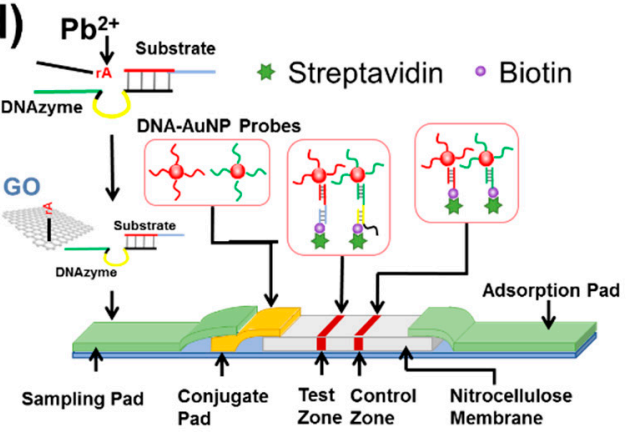

Figure 2. Crosslinking assembly of DNA-AuNPs for heavy metal detection. (a) Heavy metal as the crosslinker for the DNA-AuNP assembly. (b) $\mathrm{Hg}^{2+}$ detection based on the melting temperature of DNA-AuNP assemblies that are regulated by the formation of $\mathrm{T}-\mathrm{Hg}{ }^{\mathrm{II}}-\mathrm{T}$ duplexes. (c) $\mathrm{Pb}^{2+}$ detection based on the DNA-AuNPs network that are crosslinked by DNAzymes. (d) Schematic representation of the strip biosensor for $\mathrm{Pb}^{2+}$ detection based on GR-5 DNAzyme and AuNPs.

Due to $\mathrm{Hg}^{2+}$-mediated base pairing of $\mathrm{T}-\mathrm{T}$ mismatch, two functional ligands that both involve $\mathrm{T}$ may also be connected in the presence of $\mathrm{Hg}^{2+}[33,80]$. It has also been reported that $\mathrm{CH}_{3} \mathrm{Hg}^{+}$binds with $\mathrm{T}$ in a stronger manner [81], which is transformed from $\mathrm{Hg}^{2+}$ by microbial processing in nature and can be accumulated through aquatic food chains with dramatically increased pathogenicity [82]. 
Aulsebrook et al. prepared AuNP probes that were modified with a $\mathrm{T}$ moiety via covalent bound between $\mathrm{Au}$ and dithiol group, which can chelate both $\mathrm{Hg}^{2+}$ and $\mathrm{CH}_{3} \mathrm{Hg}^{+}$[83]. The ligand consists of a T group linked to lipoic acid by a polyethylene glycol spacer, which helps enhance the negative charge of the AuNP probes by the lipoic acid group and thereby increases the colloidal stability through electrostatic repulsion. Upon incubation of $\mathrm{Hg}^{2+}$ or $\mathrm{CH}_{3} \mathrm{Hg}^{+}$at $40{ }^{\circ} \mathrm{C}$ for $5 \mathrm{~min}$, the $\mathrm{AuNP}$ probes undergo assembly in a crosslinking manner accompanied with a color shift from red to blue. Due to the induced different hues of blue, $\mathrm{Hg}^{2+}$ and $\mathrm{CH}_{3} \mathrm{Hg}^{+}$could also be distinguished in the assay. Nevertheless, minimal spectral change could be observed for $\mathrm{Hg}^{2+}$ at concentrations lower than $20 \mu \mathrm{M}$, and a limit of detection (LOD) of $\sim 15 \mu \mathrm{M}$ was obtained.

In the above detection scheme, AuNPs were crosslinked by formation of the complex of $\mathrm{Hg}$ species and a T-based moiety anchored on AuNPs. Lee et al. further developed a selective and sensitive colorimetric method for $\mathrm{Hg}^{2+}$ detection, which relied on the use of two types of DNA-AuNPs that show complementary sequences, except for an intentional T-T mismatch (Figure 2b) [84]. In this design, $\mathrm{Hg}^{2+}$ could complex with the T-T mismatch and help form a tightly crosslinked assembly that have higher melting temperatures. In the absence of $\mathrm{Hg}^{2+}$, crosslinked AuNPs appeared purple, which appeared red when melted at $\sim 46^{\circ} \mathrm{C}$. By measuring the melting temperature of the DNA-AuNPs in the presence of $\mathrm{Hg}^{2+}$ at different concentrations, a linear detection range over $100-2000 \mathrm{nM}$ of $\mathrm{Hg}^{2+}$ was observed, with the LOD determined to be $\sim 100 \mathrm{nM}$ for the system. Xue et al. further improved the detection system for $\mathrm{Hg}^{2+}$ [85]. They prepared three DNA-probes, among which one of the DNA-probes acted as a bridge between the other two DNA-probes anchored on AuNPs. By controlling the number of $\mathrm{T}-\mathrm{T}$ mismatches in the complex formed by the three probes, the melting point of the complex can be suppressed below the ambient temperature. $\mathrm{Hg}^{2+}$ strengthens the complex and improved the melting temperature over $40{ }^{\circ} \mathrm{C}$, distinguishing $\mathrm{Hg}^{2+}$ from other metal ions that have little impact on the melting points of the system. Similar to the complex of T-HgII-T, C-AgI-C can be formed using an $\mathrm{Ag}^{+}$and $\mathrm{C}-\mathrm{C}$ mismatch, which is useful for designing a colorimetric sensor for $\mathrm{Ag}^{+}$[86]. Chen et al. also constructed a visual biosensor using two types of DNA-AuNPs that can be bridged by $\mathrm{Ag}^{+}$, based on $\mathrm{C}-\mathrm{Ag}^{\mathrm{I}}-\mathrm{C}$ formation for the detection of $\mathrm{Ag}^{+}[87,88]$.

In addition to binding with metals, some DNA sequences have been selected in vitro to catalyze the cleavage of phosphodiester bond in RNA, namely DNAzyme. DNAzyme-based colorimetric biosensing of $\mathrm{Pb}^{2+}$ has also been developed. Liu and $\mathrm{Lu}$ reported a method for $\mathrm{Pb}^{2+}$ detection using DNAzyme-linked DNA-AuNP networks, which was formed by hybridization among DNAzyme, the corresponding substrate chain and DNA-AuNP in a "head-to-tail" manner (Figure 2c) [89]. The Pb" detection range of $100 \mathrm{nM}$ to $4 \mu \mathrm{M}$ was obtained. In 2004, Liu and Lu future reported a faster detection procedure that could be operated at ambient temperature [90]. In that work, AuNPs with larger size $(42 \mathrm{~nm})$ were arranged in a "tail-to-tail" manner in the assembly, which responded rapidly $(<10 \mathrm{~min})$ to the presence of $\mathrm{Pb}^{2+}$ in comparison to the previous AuNP probes (2 h), although the detection limit (400 nM) for $\mathrm{Pb}^{2+}$ was not as low as that in the previous approach.

In order to realize fast and convenient detection in the field, colorimetric detection based on DNA-AuNPs strip has recently become a research hotspot. Wang and co-workers established a $\mathrm{Pb}^{2+}$ biosensor using GR-5 DNAzyme with the help of graphene oxide (GO) [91]. On the paper strip, two types of DNA-AuNP probes that were complementary to the green part of the DNAzyme and the red part of the substrate, respectively, were embedded in the conjugate pad. By linking streptavidin anchored on the nitrocellulose membrane, biotinylated DNAs (biotin-DNA) were immobilized in the test zone (TZ) and the control zone (CZ). In the TZ, two types of biotin-DNAs were immobilized to capture the DNA-AuNP probes (Figure 2d). One biotin-DNA formed a sandwich complex with the yellow part of the DNAzyme and a DNA-AuNP, while the other complexed with the blue part of the substrate and the other DNA-AuNP. In the CZ, two types of biotin-DNA probes were designed to bind both DNA-AuNP probes. When the sample contains $\mathrm{Pb}^{2+}$, the black part in the DNAzyme containing rA was released due to the substrate cleavage and then intercepted by GO through a stacking interaction. The rest of the DNAzyme could pass through the conjugation pad by capillary 
force, complexing to the DNA-AuNP probes from the pad and the biotin-DNAs and leaving a red line on the $\mathrm{TZ}$ for signifying $\mathrm{Pb}^{2+}$. Due to the specific $\pi$-stacking interaction between the ribose ring of the DNAzyme and the carbon hexagon in GO, the DNA-AuNP-based lateral flow sensor exhibited stronger specificity for $\mathrm{Pb}^{2+}$, thus reducing false positive interference by removing unhybridized DNAzyme and substrate. The LOD of the sensor was as low as $0.05 \mathrm{nM}$, which is much lower than the maximum allowable levels of $\mathrm{Pb}^{2+}$ in drinking water set by the WHO $(48 \mathrm{nM})$ and the U.S. Environmental Protection Agency (EPA) (72 nM) [92,93].

\subsection{Electrostatic Interaction-Mediated Assembly for Heavy Metal Detection}

Colloidal nanoparticles are usually dispersed through interparticle electrostatic repulsion. The alternation of electrostatic force among nanoparticles may cause a change in their dispersion status. Based on electrostatic-mediated AuNP assembly/disassembly, various biosensors for heavy metals have also been established. In these works, the binding behavior of DNA to an analyte on AuNP is used to alter the interparticle electrostatic interaction, enabling change in the dispersion state of AuNPs, and thereby the detection of the analyte.

\subsubsection{Detection Based on Change in Electrostatic Interaction of Unmodified AuNPs}

DNA can be adsorbed to the surface of AuNP by electrostatic and hydrophobic interaction [94]. Upon binding to a target heavy metal, DNA can undergo significant structural change. The binding behavior is often accompanied with change in the interactions among DNA-AuNPs, which further causes color change of the colloid (Figure 3a) [55].

(a)

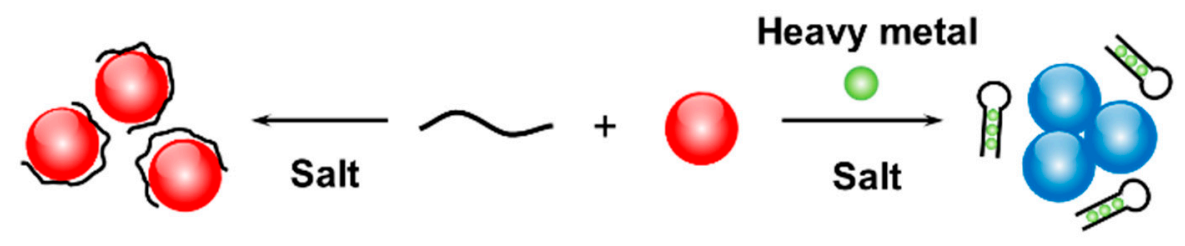

(b)

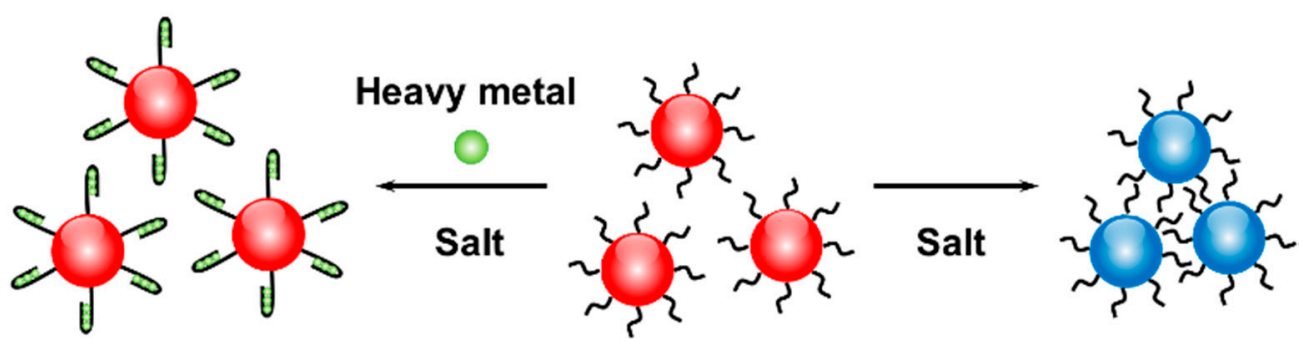

Figure 3. Electrostatic interaction-mediated assembly of DNA-AuNPs for heavy metal detection.

(a) Assembly of unmodified AuNPs controlled by heavy metal binding-regulated DNA adsorption.

(b) Assembly of DNA-grafted AuNPs controlled by heavy metal-induced DNA folding.

Formation of $\mathrm{T}-\mathrm{Hg}^{\mathrm{II}}-\mathrm{T}$ by a T-rich DNA and $\mathrm{Hg}^{2+}$ usually induces folding of the DNA. Liu and co-workers designed a DNA-AuNP probe for detecting $\mathrm{Hg}^{2+}$ visually through a $\mathrm{T}-\mathrm{Hg}{ }^{\mathrm{II}}-\mathrm{T}$ interaction [95]. In that work, they took AuNPs (13 nm diameter) and random-coil poly-Tn ssDNA in a salt solution, in which DNA adsorbed on the surface of AuNPs. Due to the high negative charge density of DNA molecules on each AuNP surface, AuNP kept dispersed state in red because of the protection by DNA. With the addition of $\mathrm{Hg}^{2+}$, a folded $\mathrm{Hg}^{2+}$-DNA complex involving $\mathrm{T}-\mathrm{Hg}{ }^{\mathrm{II}}-\mathrm{T}$ forms, causing the complex to be desorbed from the AuNPs. Without the electrostatic repulsion provided by the adsorbed DNA, the AuNPs tend to aggregate. At a signal noise ratio of 3 , the LOD was estimated to be $250 \mathrm{nM}$. Due to the $\mathrm{C}-\mathrm{Ag}^{\mathrm{I}}-\mathrm{C}$ formation by $\mathrm{C}$-rich DNA and $\mathrm{Ag}^{+}$, a detection scheme for $\mathrm{Ag}^{+}$could also be designed that is similar to the one mentioned above [96]. As a successive 
work to Liu's report, Chen et al. realized field analysis of $\mathrm{Hg}^{2+}$ in river water with a paper-based device [97]. They first utilized an identical approach to detect $\mathrm{Hg}^{2+}$ in pond or polluted water samples using colloidal DNA-AuNPs, which underwent a color shift from red to blue. Next, the mixture was spotted on a paper for color signal enhancement. By cloud computing via a smartphone, the detection results for $\mathrm{Hg}^{2+}$ for the real samples can be readily transmitted for readout and data storage. The total test time was $\sim 40 \mathrm{~min}$ with a LOD of $\sim 50 \mathrm{nM}$ for $\mathrm{Hg}^{2+}$-spiked pond and river water was achieved.

Toward arsenic recognition and detection, Kim et al. have screened an arsenic-bound DNA aptamer named Ars-3 in vitro, which consists of 100 nucleotides and exhibits high affinity to As ${ }^{3+}$ [98]. Zhan et al. designed a simple colorimetric detection method based on assembly of AuNPs, which could be regulated using the specific interaction between Ars-3 and $\mathrm{As}^{3+}$ [99]. Specifically, Ars-3 aptamers can be adsorbed onto the surfaces of AuNPs through base-gold interaction, which protected the AuNPs from spontaneous assembly even at high ionic strength. In the presence of $\mathrm{As}^{3+}$, however, the $\mathrm{As}^{3+}$ bound with Ars-3 and formed a complex that resulted in the base of aptamer, which was not exposed and lost the ability to adsorb on the surface of AuNPs. Consequently, the AuNPs assembled with the induction of salt with a color change from red to blue. This sensor had a detection limit of $1.26 \mathrm{ppb}(16.8 \mathrm{nM})$ for $\mathrm{As}^{3+}$, which is lower than the maximum permissible concentration $(10 \mathrm{ppb})$ of arsenic in drinking water determined by WHO [100].

In arsenic and its compounds, As (III) species are the most toxic and usually present in the form of arsenite. Liang and co-workers proposed a label-free colorimetric strategy to detect arsenite based on the target-induced change in the interfacial electrostatics of DNA-AuNPs [101]. The arsenite was in the form of $\mathrm{H}_{3} \mathrm{AsO}_{3}$, which can easily bind to the ssDNA rich in $\mathrm{G}$ and $\mathrm{T}$, via the strong hydrogen bond [102]. The ssDNA aptamer rich in G and T and AuNPs could be integrated as the arsenite probe by adsorption. While the binding between arsenite and the aptamer altered the charge property of the aptamer, releasing the aptamer from the AuNP surfaces and inducing assembly and color change of AuNPs. The LOD was 50 ppb (396.8 nM) achieved with the naked eye and $0.5 \mathrm{ppb}(4.0 \mathrm{nM})$ with UV/Vis spectrometry. Despite a different sequence and length, G and T-rich ssDNA sequences also function as aptamers for some other heavy metals, such as $\mathrm{Cd}^{2+}$. Wu et al. screened a new ssDNA aptamer named Cd-4 using the SELEX technique, which was rich in $\mathrm{G}$ and $\mathrm{T}$ and can specifically recognize $\mathrm{Cd}^{2+}$ [103]. The dissociation constant of Cd-4 aptamer was determined to be $34.5 \mathrm{nM}$ for $\mathrm{Cd}^{2+}$. Subsequently, by using a Cd-4 aptamer, they tested $\mathrm{Cd}^{2+}$ in aqueous solution containing poly diallyl dimethyl ammonium chloride (PDDA) that can bind to Cd-4 aptamer. As a water-soluble cationic polymer, PDDA can cause the assembly of AuNPs. It binds to aptamers through non-specific electrostatic interactions. In the presence of $\mathrm{Cd}^{2+}$, the Cd-4 interacted strongly with $\mathrm{Cd}^{2+}$, resulting in the failure of binding with PDDA. Consequently, the assembly of AuNPs took place in the presence of PDDA, causing a significant change in color from wine red to blue. By using this method, $\mathrm{Cd}^{2+} \mathrm{can}^{\mathrm{be}}$ detected at a concentration as low as $0.5 \mathrm{ppb}(4.6 \mathrm{nM})$, which is lower than the maximum level (5 ppb) of cadmium in drinking water defined by EPA [103].

Unlike the ssDNA aptamers that fold through heavy metal binding, $\mathrm{Pb}^{2+}$-specific DNAzyme/substrate in a double-strand can release short nucleic acid segments for the protection of AuNPs in the presence of $\mathrm{Pb}^{2+}$. A blue-to-red "signal on" plasmonic sensor may be designed based on this process [104]. Taking advantage of the high specific selectivity of 8-17E DNAzyme for $\mathrm{Pb}^{2+}$, Wang et al. designed a label-free sensor to detect $\mathrm{Pb}^{2+}$ in less than $10 \mathrm{~min}$ [105]. In the presence of $\mathrm{Pb}^{2+}$, a part of the substrate chain was cut off, and this part was adsorbed on the surface of AuNPs, causing particles' state from aggregation to dispersion. Furthermore, Memon et al. performed a colorimetric ultrasensitive detection of $\mathrm{Pb}^{2+}$ with DNAzyme [106]. In their design, 5-bases were removed from 8-17 DNAzyme to promote the separation of ssDNA fragments after substrate cleavage in the presence of $\mathrm{Pb}^{2+}$. The isolated ssDNA adsorbed on AuNPs and prevented them from assembly at high ionic strength. As a result, $\mathrm{Pb}^{2+}$ caused a rapid color change of the AuNP solution from blue to red. The limit of detection of $\mathrm{Pb}^{2+}$ based on this design was as low as $0.2 \mathrm{nM}$. 


\subsubsection{Detection by Modulating Electrostatic Interaction of DNA-Grafted AuNPs}

In the above strategy, DNA can adsorb onto and desorb from AuNPs depending on its recognition behavior to heavy metal targets. The resultant interfacial electrostatic force among AuNPs is responsive for heavy metal detection. When DNAs are grafted on AuNP surfaces, the DNA-AuNPs need to be considered as a whole when analyzing the electrostatic interactions among them.

For instance, folded DNA exhibits high charge density compared to its unfolded counterpart, and the resultant stronger electrostatic repulsion between folded DNA are capable of stabilizing AuNPs against salt-induced assembly (Figure 3b) [70]. It has also been reported that the folding event of ssDNA densely grafted on AuNPs can cause the release of some of the DNA molecules from the AuNP surface [107]. By using the different strength of positively charged methylene blue (MB) to ssDNA and folded DNA, interestingly, Wang et al. developed a magnetoplasmonic nanoparticles $\left(\mathrm{Fe}_{3} \mathrm{O}_{4} @ \mathrm{AuNP}\right)$-based colorimetric sensor for detection of $\mathrm{Hg}^{2+}$ that is dependent on the color indication with $\mathrm{MB}$ [108]. As a positively charged organic dye with aromatic rings, MB binds more tightly to dsDNA than ssDNA by intercalating into dsDNA through $\pi-\pi$ stacking [109], leading to a color change of the solution when the conformation of DNA grafted on $\mathrm{Fe}_{3} \mathrm{O}_{4} @ \mathrm{AuNP}$ transformed from hybridization to folding. In the absence of $\mathrm{Hg}^{2+}$, aptamers on AuNPs hybridized with two ssDNA segments. The resulting long DNA polymers bound to MB, and thus, the solution color underwent a great decay upon magnetic separation. However, the recognition of $\mathrm{Hg}^{2+}$ with DNA-AuNPs on $\mathrm{Fe}_{3} \mathrm{O}_{4}$ resulted in transformation of the DNA derivative from a linear to a hairpin structure by forming $\mathrm{T}-\mathrm{Hg}$ II-T, which has a lower binding capability to methylene blue. Therefore, a pronounced blue color was obtained upon magnetic separation. The absorbance of the residual MB solution was measured at $663 \mathrm{~nm}$ for quantification of $\mathrm{Hg}^{2+}$ with a LOD of $0.7 \mathrm{nM}$ and a linear range of 1-300 nM. The above results also indicated the considerable potential of engineering multiple interfaces of DNA-AuNPs on single $\mathrm{Fe}_{3} \mathrm{O}_{4}$ nanoparticles.

\subsection{Base Pair Stacking-Mediated Assembly for Detection}

Different from the above strategies, the control of single base pairing/unpairing in the outermost terminals of DNA that grafted on AuNPs has recently been developed for visual detection. According to the pioneering works of Maeda and co-workers, for AuNPs that are densely modified with dsDNA, the pairing status of the outermost base(s) of the dsDNA-AuNPs do matter to the colloidal stability. When DNA terminal bases are complementary, there is hydrophobic interaction (e.g., $\pi$ - $\pi$ stacking) between the blunt ends, which causes a sharp decay in the colloid stability of AuNPs and thereby rapid assembly in a non-crosslinking fashion (Figure 4a) [72,73,75].

When the terminal bases are mismatched, the AuNPs remain steadily dispersed even at a high salt concentration. This can be attributed to the fraying motion of the unpaired bases that generates strong entropic repulsion. Since the outermost base pairs can be designated to chelate heavy metals, such as $\mathrm{Hg}^{2+}$ and $\mathrm{Ag}^{+}$, the non-crosslinking assembly of DNA-AuNPs have implications in heavy metal detection. Kanayama et al. designed a nano-sensor that can visually detect $\mathrm{Hg}^{2+}$ in 1 min [77]. On account of the T-T mismatch at the antepenultimate position of DNA, the dsDNA-AuNP colloid remains highly stable and dispersed. By adding $\mathrm{Hg}^{2+}$ to form a $\mathrm{T}-\mathrm{Hg}$ II-T complex, the entropic repulsion decreased and the AuNPs aggregated and precipitated rapidly, resulting in a distinct color change from red to colorless. The visual detection limit of this method for $\mathrm{Hg}^{2+}$ was estimated to be $\sim 0.5 \mu \mathrm{M}$. By fine design of the terminal bases of DNA grafted on AuNPs, they further constructed a series of colloidal logic gates regulated by $\mathrm{T}-\mathrm{Hg}^{\mathrm{II}}-\mathrm{T}$ and $\mathrm{C}-\mathrm{Ag} \mathrm{I}-\mathrm{C}$ formation [76]. The rigidity of dsDNA can also be modulated to control colloidal entropic repulsion. Diao et al. constructed a "turn-off" detection system for $\mathrm{Pb}^{2+}$ with GR-5 DNAzyme-grafted AuNPs [110], which have blunt ends at the outermost terminal of the DNAzyme (Figure 4b). Therefore, the AuNPs aggregated as a result of stacking attraction. In presence of $\mathrm{Pb}^{2+}$, the substrate chain would be cleaved, and the loop of the enzyme chain became flexible and greatly enhanced the colloidal entropic repulsion., bringing the 
AuNP aggregates back to the state of dispersion. The detection limit of this method was $8.0 \mathrm{nM}$, which was lower than that reported for the electrochemical detection method [111].

(a)
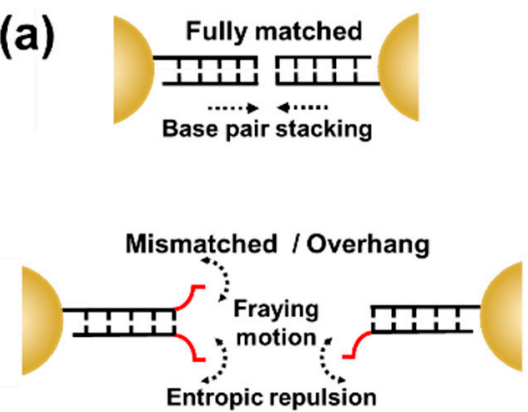

(c)

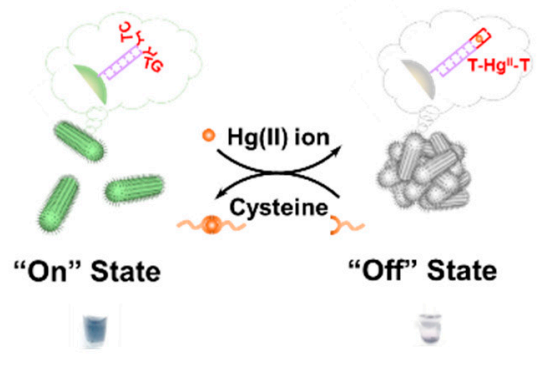

(b)

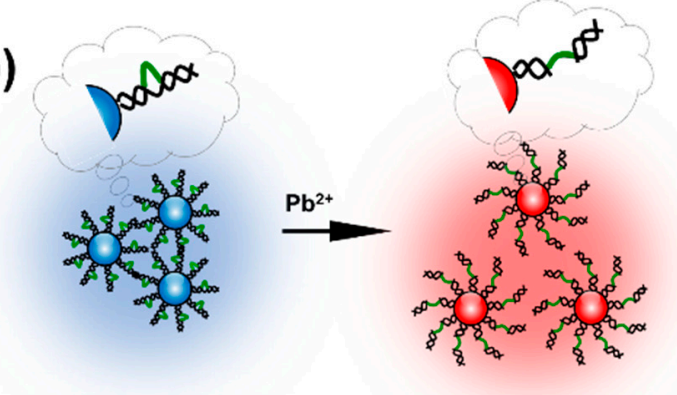

(d)

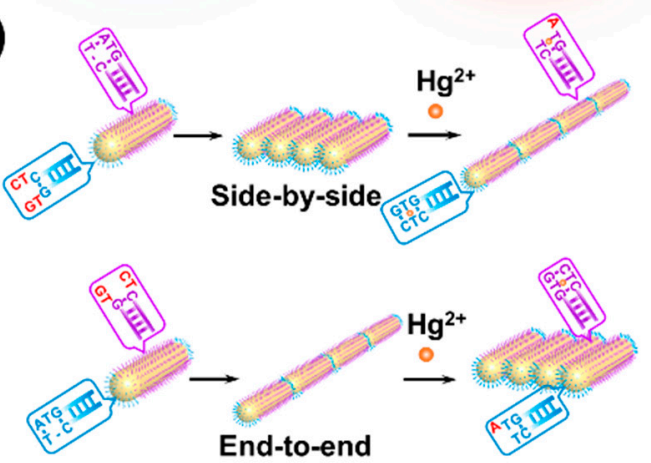

Figure 4. Base pair stacking-mediated assembly of DNA-AuNPs for heavy metal detection. (a) Schematic

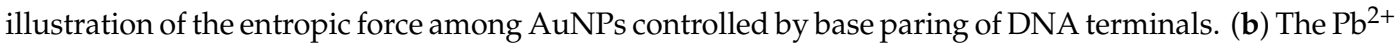
detection system based on the decreased rigidity of the DNAzyme grafted on the surface of AuNP. (c) Switching of dsDNA-AuNRs' assembly state regulated by $\mathrm{Hg}^{2+} /$ Cysteine-controlled DNA terminal base paring. (d) Schematic diagrams for the $\mathrm{Hg}^{2+}$-directed assembly of AuNRs achieved by regioselective modification of DNA with fine designed terminals.

In addition to spherical nanoparticles, the entropic interfacial behavior is also applicable to the nanostructures with different morphologies, such as gold nanorod (AuNR) and gold nanotriangle (AuNT) [38]. Zhang et al. prepared a plasmon switch to rapidly detect two targets based on dsDNA-AuNRs that show a T-T mismatch at the penultimate position (Figure 4c) [112]. In the presence of $\mathrm{Hg}^{2+}$, the $\mathrm{T}-\mathrm{T}$ mismatch of the dsDNA-AuNRs are transformed into a $\mathrm{T}-\mathrm{Hg}^{\mathrm{II}}-\mathrm{T}$ pairing, causing spontaneous non-crosslinking assembly of the dsDNA-AuNRs. On the contrary, the resultant dsDNA-AuNRs that have $\mathrm{T}-\mathrm{Hg}^{\mathrm{II}}-\mathrm{T}$ at the outermost dsDNA layer have $\mathrm{Hg}^{2+}$ extracted to reproduce the T-T mismatch upon introduction of cysteine, causing the color shift from colorless back to green. This switch can be quickly and repeatedly cycled at room temperature, and be used to detect low-concentration $\mathrm{Hg}^{2+}$ down to $10 \mathrm{nM}$. This concentration reaches the maximum allowable level of $\mathrm{Hg}^{2+}$ in drinking water as defined by EPA [113].

One unique characteristic of anisotropic nanoparticles is the uneven surface reactivity. For instance, the ends of AuNR are more active in ligand attachment and metal deposition due to the large curvature and less stable crystal structure [114,115]. By region-selective DNA modification, Wang et al. achieved directed assembly of AuNRs in side-by-side and end-to-end manners (Figure 4d) [48]. By further anchoring specifically designed $\mathrm{Hg}^{2+}$-binding DNA on the ends or side region of the AuNRs, it is possible to prepare $\mathrm{Hg}^{2+}$-responsive side-by-side and end-to-end assemblies of AuNRs.

In comparison to its crosslinking counterpart, the non-crosslinking assembly of AuNPs has the advantage of rapid color response in the presence of an excess amount of target [67,116], thereby promising gene diagnostics once combined with polymerase chain reaction (PCR) [117]. Low-polarity 
solvents also facilitate the entropic interfacial assembly of DNA-AuNPs, making it suitable for heavy metal detection in expanded contexts [118].

\section{Comparison among the Three Strategies for Heavy Metal Detection Based on DNA-AuNPs}

By using the approaches based on electrostatic interactions, crosslinking or base pair stacking, the change of assembly state of the DNA-AuNPs caused by the recognition behavior of the functional DNAs generates the colorimetric signal for target heavy metals. However, the three approaches have their own advantages and disadvantages. Representative DNA-AuNP probes designed using the three strategies are listed in Table 1, and the selectivity of each methods were evaluated by the signal intensities of interfering ions. If the signals of more than one interfering ion are much higher than blank, the selectivity were judged to be moderate. According to the literature discussed above, the strategy of electrostatic interaction-mediated assembly based on DNA adsorption onto AuNPs is relatively easy to design and widely employed for heavy metal sensing due to the target-responsive structural switching feature of ssDNA, which often causes a change in the charge distribution of DNA. However, it is associated with the nonspecific adsorption of DNA on AuNPs, often leading to broad distribution of equilibrium constant in desorption [119]. Both the crosslinking- and entropic force-based methods, which mostly rely on the use of DNA-grafted AuNPs, avoid the problem of non-specific adsorption, but they are limited to the detection of $\mathrm{Hg}^{2+}$ and $\mathrm{Pb}^{2+}$ despite improved selectivity. An advantage of base pair stacking-based method is the capability of detection at high ionic strength, which promises heavy metal detection in real samples that are probably difficulty to achieve with the other two methods.

Table 1. Colorimetric detection of heavy metals by different strategies based on the use of DNA-AuNPs.

\begin{tabular}{ccccc}
\hline Mechanisms & Targets & LOD & Selectivity & Ref. \\
\hline \multirow{5}{*}{ Crosslinking } & $\mathrm{Hg}^{2+} / \mathrm{CH}_{3} \mathrm{Hg}^{+}$ & $15 / 1.7 \mu \mathrm{M}$ & Good & {$[83]$} \\
& $\mathrm{Hg}^{2+}$ & $100 \mathrm{nM}$ & Moderate & {$[84]$} \\
& $\mathrm{Hg}^{2+}$ & $3 \mu \mathrm{M}$ & Good & {$[85]$} \\
& $\mathrm{Pb}^{2+}$ & $100 \mathrm{nM}$ & Moderate & {$[89]$} \\
& $\mathrm{Pb}^{2+}$ & $400 \mathrm{nM}$ & Good & {$[90]$} \\
& $\mathrm{Pb}^{2+}$ & $0.05 \mathrm{nM}$ & Good & {$[91]$} \\
\hline \multirow{5}{*}{ Electrostatic } & $\mathrm{Hg}^{2+}$ & $250 \mathrm{nM}$ & Good & {$[95]$} \\
& $\mathrm{Hg}^{2+}$ & $50 \mathrm{nM}$ & Moderate & {$[97]$} \\
& $\mathrm{As}^{3+}$ & $16.8 \mathrm{nM}$ & Moderate & {$[99]$} \\
& $\mathrm{Arsenite}^{2+}$ & $4.0 \mathrm{nM}$ & Moderate & {$[101]$} \\
& $\mathrm{Cd}^{2+}$ & $4.6 \mathrm{nM}$ & Moderate & {$[103]$} \\
& $\mathrm{Pb}^{2+}$ & $3 \mathrm{nM}$ & Good & {$[105]$} \\
& $\mathrm{Pb}^{2+}$ & $0.2 \mathrm{nM}$ & Moderate & {$[106]$} \\
& $\mathrm{Hg}^{2+}$ & $0.7 \mathrm{nM}$ & Moderate & {$[108]$} \\
\hline \multirow{5}{*}{ Base pair stacking } & $\mathrm{Hg}^{2+}$ & $0.5 \mu \mathrm{M}$ & Good & {$[77]$} \\
& $\mathrm{Hg}^{2+}$ & $10 \mathrm{nM}$ & Good & {$[112]$} \\
& $\mathrm{Pb}^{2+}$ & $8.0 \mathrm{nM}$ & Moderate & {$[110]$} \\
\hline
\end{tabular}

\section{Conclusions and Perspectives}

Since the discovery of functional DNAs for metals including aptamers and DNAzyme, detection of heavy metals based on the combination of DNA and AuNPs has been a lasting research interest in the relevant fields. With hundreds of papers published yearly, great progress has been achieved in the field of DNA-AuNPs for heavy metal sensing. For instance, many detection approaches based on the DNA-binding responsive interface of DNA-AuNPs have been developed, such as electrostatic interactions, crosslinking and base pair stacking. Additionally, the LOD for their colorimetric detection has also been lowered by many orders of magnitude. Thanks to the tremendous efforts people have devoted to this research field, recent years have also witnessed a quiet shift of research interest 
in DNA-AuNPs-based biosensing from principle-of-concept demonstration in the laboratory to practical applications for real samples. Portable devices, such as test strips, have gained an increasing popularity for field analysis with a computer or a smartphones as a data processor $[120,121]$. Regarding applications in fields ranging from environmental and biological analysis to food safety, challenges and opportunities are ahead as well. First, a major intrinsic problem in heavy metal detection using interface-engineered DNA-AuNPs is the relative low affinity in metal binding, particularly in the nanomolar range. This may cause a weak response of the DNA-AuNP interface to a heavy metal target, resulting in low detection sensitivity and selectivity. It is, thus, suggested that the selection of aptamers for heavy metals with higher affinity is urgently needed. Second, the binding mechanism between an aptamer and its heavy metal target (e.g., Cd, As) mostly remain less known, which is essential for finer design of interface-driven DNA-AuNP probes. Third, although detection of the typical heavy metal ions including $\mathrm{Hg}^{2+}, \mathrm{Pb}^{2+}, \mathrm{Cd}^{2+}$ and $\mathrm{As}^{3+}$ has received remarkable progress, in nature the heavy metals exist in a range of oxidation states as organic compounds, which exhibit high toxicity to human health and the ecological system. Accordingly, the real-life application of DNA-AuNPs for environmental samples is urgently needed. Finally, the exploitation of smart optical readers, including smartphones, would be a future direction for biosensors based on DNA-AuNPs. Based on the integration of gold nanostructures as indicators and the portable color readers for quantification, convenient and multiplex colorimetric detection of heavy metals for in-field analysis can be expected.

Author Contributions: Conceptualization, G.W., Z.H. and H.Y.; investigation, Z.H. and H.Y.; writing-original draft preparation, Z.H. and H.Y.; writing-review and editing, G.W. and C.-C.C.; supervision, G.W. and X.L.; funding acquisition, G.W. All authors have read and agreed to the published version of the manuscript.

Funding: This work was funded by the Shandong Provincial Soft Science Research Program (2019RKE29001) and the Shandong Provincial Science Foundation (ZR2019QC011). This work was also supported in part by the Fundamental Research Funds for the Central Universities.

Conflicts of Interest: The authors declare no financial or commercial conflict of interest.

\section{References}

1. Kurup, P.; Sullivan, C.; Hannagan, R.; Yu, S.; Azimi, H.; Robertson, S.; Ryan, D.; Nagarajan, R.; Ponrathnam, T.; Howe, G. A review of technologies for characterization of heavy metal contaminants. Indian Geotech. J. 2017, 47, 421-436. [CrossRef]

2. Hutton, M. Human health concerns of lead, mercury, cadmium and arsenic. Lead Mercury Cadmium Arsen. Environ. 1987, 31, 53-68.

3. Kim, H.S.; Kim, Y.J.; Seo, Y.R. An Overview of carcinogenic heavy metal: Molecular toxicity mechanism and prevention. J. Cancer Prev. 2015, 20, 232-240. [CrossRef] [PubMed]

4. World Health Organization. Ten Chemicals of Major Public Health Concern; World Health Organization: Geneva, Switzerland, 2010; pp. 1-4.

5. Aragay, G.; Pons, J.; Merkoçi, A. Recent trends in macro-, micro-, and nanomaterial-based tools and strategies for heavy-metal detection. Chem. Rev. 2011, 111, 3433-3458. [CrossRef] [PubMed]

6. Saidur, M.R.; Aziz, A.R.A.; Basirun, W.J. Recent advances in DNA-based electrochemical biosensors for heavy metal ion detection: A review. Biosens. Bioelectron. 2017, 90, 125-139. [CrossRef] [PubMed]

7. Jan, A.T.; Azam, M.; Siddiqui, K.; Ali, A.; Choi, I.; Haq, Q.M. Heavy metals and human health: Mechanistic insight into toxicity and counter defense system of antioxidants. Int. J. Mol. Sci. 2015, 16, 29592-29630. [CrossRef] [PubMed]

8. Tchounwou, P.B.; Yedjou, C.G.; Patlolla, A.K.; Sutton, D.J. Heavy metal toxicity and the environment. In Molecular, Clinical and Environmental Toxicology; Springer: Berlin/Heidelberg, Germany, 2012; pp. $133-164$.

9. Bansod, B.; Kumar, T.; Thakur, R.; Rana, S.; Singh, I. A review on various electrochemical techniques for heavy metal ions detection with different sensing platforms. Biosens. Bioelectron. 2017, 94, 443-455. [CrossRef] [PubMed]

10. Zhang, J.; Sun, X.; Wu, J. Heavy metal ion detection platforms based on a glutathione probe: A mini review. Appl. Sci. 2019, 9, 489. [CrossRef] 
11. Fang, X.; Tan, W. Aptamers generated from Cell-SELEX for molecular medicine: A chemical biology approach. Acc. Chem. Res. 2010, 43, 48-57. [CrossRef]

12. Xiao, M.; Lai, W.; Man, T.; Chang, B.; Li, L.; Chandrasekaran, A.R.; Pei, H. Rationally engineered nucleic acid architectures for biosensing applications. Chem. Rev. 2019, 119, 11631-11717. [CrossRef]

13. Jeevanandam, J.; Tan, K.X.; Danquah, M.K.; Guo, H.; Turgeson, A. Advancing aptamers as molecular probes for cancer theranostic applications-The role of molecular dynamics simulation. Biotechnol. J. 2020, 15, 1900368. [CrossRef] [PubMed]

14. Willner, I.; Shlyahovsky, B.; Zayats, M.; Willner, B. DNAzymes for sensing, nanobiotechnology and logic gate applications. Chem. Soc. Rev. 2008, 37, 1153-1165. [CrossRef]

15. Long, F.; Zhu, A.; Shi, H. Recent advances in optical biosensors for environmental monitoring and early warning. Sensors 2013,13, 13928-13948. [CrossRef]

16. Wang, G.; Chen, Z.; Wang, W.; Yan, B.; Chen, L. Chemical redox-regulated mesoporous silica-coated gold nanorods for colorimetric probing of $\mathrm{Hg}^{2+}$ and $\mathrm{S}^{2-}$. Analyst 2011, 136, 174-178. [CrossRef]

17. Stojanovic, M.N.; Landry, D.W. Aptamer-based colorimetric probe for cocaine. J. Am. Chem. Soc. 2002, 124, 9678-9679. [CrossRef]

18. Celiesiute, R.; Ramanaviciene, A.; Gicevicius, M.; Ramanavicius, A. Electrochromic sensors based on conducting polymers, metal oxides, and coordination complexes. Crit. Rev. Anal. Chem. 2019, 49, 195-208. [CrossRef]

19. Liu, X.; Tang, Y.; Wang, L.; Zhang, J.; Song, S.; Fan, C.; Wang, S. Optical detection of mercury(II) in aqueous solutions by using conjugated polymers and label-free oligonucleotides. Adv. Mater. 2007, 19, 1471-1474. [CrossRef]

20. Deshmukh, M.A.; Shirsat, M.D.; Ramanaviciene, A.; Ramanavicius, A. Composites based on conducting polymers and carbon nanomaterials for heavy metal ion sensing (Review). Crit. Rev. Anal. Chem. 2018, 48, 293-304. [CrossRef] [PubMed]

21. Kolpashchikov, D.M. Split DNA enzyme for visual single nucleotide polymorphism typing. J. Am. Chem. Soc. 2008, 130, 2934-2935. [CrossRef]

22. Wang, L.; Li, J.; Song, S.; Li, D.; Fan, C. Biomolecular sensing via coupling DNA-based recognition with gold nanoparticles. J. Phys. D Appl. Phys. 2009, 42, 203001. [CrossRef]

23. Liu, A.; Wang, G.; Wang, F.; Zhang, Y. Gold nanostructures with near-infrared plasmonic resonance: Synthesis and surface functionalization. Coord. Chem. Rev. 2017, 336, 28-42. [CrossRef]

24. Wang, G.; Akiyama, Y.; Kanayama, N.; Takarada, T.; Maeda, M. Non-crosslinking aggregation of DNA-functionalized gold nanoparticles for gene diagnosis and directed assembly. In Targeted Nanosystems for Therapeutic Applications: New Concepts, Dynamic Properties, Efficiency, and Toxicity; American Chemical Society: Washington, DC, USA, 2019; Volume 1309, pp. 119-138.

25. Wang, G.; Wang, Y.; Chen, L.; Choo, J. Nanomaterial-assisted aptamers for optical sensing. Biosens. Bioelectron. 2010, 25, 1859-1868. [CrossRef] [PubMed]

26. Wang, R.E.; Zhang, Y.; Cai, J.; Cai, W.; Gao, T. Aptamer-based fluorescent biosensors. Curr. Med. Chem. 2011, 18, 4175-4184. [CrossRef] [PubMed]

27. Liu, B.; Liu, J. Interface-driven hybrid materials based on DNA-functionalized gold nanoparticles. Matter 2019, 1, 825-847. [CrossRef]

28. Tian, Y.; Zhang, L.; Wang, L. DNA-functionalized plasmonic nanomaterials for optical biosensing. Biotechnol. J. 2020, 15, 1800741. [CrossRef]

29. Zhou, W.; Saran, R.; Liu, J. Metal sensing by DNA. Chem. Rev. 2017, 117, 8272-8325. [CrossRef]

30. Zhang, X.-B.; Kong, R.-M.; Lu, Y. Metal ion sensors based on DNAzymes and related DNA molecules. Annu. Rev. Anal. Chem. 2011, 4, 105-128. [CrossRef]

31. Farzin, L.; Shamsipur, M.; Sheibani, S. A review: Aptamer-based analytical strategies using the nanomaterials for environmental and human monitoring of toxic heavy metals. Talanta 2017, 174, 619-627. [CrossRef]

32. Ono, A.; Cao, S.; Togashi, H.; Tashiro, M.; Fujimoto, T.; Machinami, T.; Oda, S.; Miyake, Y.; Okamoto, I.; Tanaka, Y. Specific interactions between silver(i) ions and cytosine-cytosine pairs in DNA duplexes. Chem. Commun. 2008, 4825-4827. [CrossRef]

33. Tanaka, Y.; Oda, S.; Yamaguchi, H.; Kondo, Y.; Kojima, C.; Ono, A. 15N-15N J-coupling across HgII: Direct observation of $\mathrm{Hg}^{\mathrm{II}}$-mediated $\mathrm{T}-\mathrm{T}$ base pairs in a DNA duplex. J. Am. Chem. Soc. 2007, 129, 244-245. [CrossRef] 
34. Carnerero, J.M.; Jimenez-Ruiz, A.; Castillo, P.M.; Prado-Gotor, R. Covalent and non-covalent DNA-gold-nanoparticle interactions: New avenues of research. ChemPhysChem 2017, 18, 17-33. [CrossRef]

35. Seok, H.; Park, T.H. Integration of biomolecules and nanomaterials: Towards highly selective and sensitive biosensors. Biotechnol. J. 2011, 6, 1310-1316. [CrossRef]

36. Hill, H.D.; Millstone, J.E.; Banholzer, M.J.; Mirkin, C.A. The role radius of curvature plays in thiolated oligonucleotide loading on gold nanoparticles. ACS Nano 2009, 3, 418-424. [CrossRef]

37. Wu, M.; Vartanian, A.M.; Chong, G.; Pandiakumar, A.K.; Hamers, R.J.; Hernandez, R.; Murphy, C.J. Solution NMR analysis of ligand environment in quaternary ammonium-terminated self-assembled monolayers on gold nanoparticles: The effect of surface curvature and ligand structure. J. Am. Chem. Soc. 2019, 141, 4316-4327. [CrossRef]

38. Wang, G.; Akiyama, Y.; Takarada, T.; Maeda, M. Rapid non-crosslinking aggregation of DNA-functionalized gold nanorods and nanotriangles for colorimetric single-nucleotide discrimination. Chem. Eur. J. 2016, 22, 258-263. [CrossRef] [PubMed]

39. Demers, L.M.; Mirkin, C.A.; Mucic, R.C.; Reynolds, R.A.; Letsinger, R.L.; Elghanian, R.; Viswanadham, G. A fluorescence-based method for determining the surface coverage and hybridization efficiency of thiol-capped oligonucleotides bound to gold thin films and nanoparticles. Anal. Chem. 2000, 72, 5535-5541. [CrossRef]

40. Park, S.-J.; Lazarides, A.A.; Storhoff, J.J.; Pesce, L.; Mirkin, C.A. The structural characterization of oligonucleotide-modified gold nanoparticle networks formed by DNA hybridization. J. Phys. Chem. B 2004, 108, 12375-12380. [CrossRef]

41. Jang, N.-H. The coordination chemistry of DNA nucleosides on gold nanoparticles as a probe by SERS. Bull. Korean Chem. Soc. 2002, 23, 1790-1800.

42. Zhang, X.; Servos, M.R.; Liu, J. Surface science of DNA adsorption onto citrate-capped gold nanoparticles. Langmuir 2012, 28, 3896-3902. [CrossRef]

43. Storhoff, J.J.; Lazarides, A.A.; Mucic, R.C.; Mirkin, C.A.; Letsinger, R.L.; Schatz, G.C. What controls the optical properties of DNA-linked gold nanoparticle assemblies? J. Am. Chem. Soc. 2000, 122, 4640-4650. [CrossRef]

44. Jans, H.; Huo, Q. Gold nanoparticle-enabled biological and chemical detection and analysis. Chem. Soc. Rev. 2012, 41, 2849-2866. [CrossRef]

45. Frens, G. Controlled nucleation for the regulation of the particle size in monodisperse gold suspensions. Nat. Phys. Sci. 1973, 241, 20-22. [CrossRef]

46. Lohse, S.E.; Murphy, C.J. The quest for shape control: A history of gold nanorod synthesis. Chem. Mater. 2013, 25, 1250-1261. [CrossRef]

47. Sajanlal, P.R.; Sreeprasad, T.S.; Samal, A.K.; Pradeep, T. Anisotropic nanomaterials: Structure, growth, assembly, and functions. Nano Rev. 2011, 2, 5883. [CrossRef]

48. Wang, G.; Akiyama, Y.; Kanayama, N.; Takarada, T.; Maeda, M. Directed assembly of gold nanorods by terminal-base pairing of surface-grafted DNA. Small 2017, 13, 1702137. [CrossRef]

49. Wang, G.; Zhang, Y.; Liang, X.; Takarada, T.; Maeda, M. Regioselective DNA modification and directed self-assembly of triangular gold nanoplates. Nanomaterials 2019, 9, 581. [CrossRef]

50. Ma, W.; Kuang, H.; Xu, L.; Ding, L.; Xu, C.; Wang, L.; Kotov, N.A. Attomolar DNA detection with chiral nanorod assemblies. Nat. Commun. 2013, 4, 2689. [CrossRef]

51. Wang, L.; Zhu, Y.; Xu, L.; Chen, W.; Kuang, H.; Liu, L.; Agarwal, A.; Xu, C.; Kotov, N.A. Side-by-side and end-to-end gold nanorod assemblies for environmental toxin sensing. Angew. Chem. Int. Ed. 2010, 49, 5472-5475. [CrossRef]

52. Blackburn, G.M.; Gait, M.J.; Loakes, D.; Williams, D.M.; Egli, M.; Flavell, A.; Allen, S.; Fisher, J.; Haq, S.I.; Pyle, A.M. Nucleic Acids in Chemistry and Biology; Royal Society of Chemistry: London, UK, 2006.

53. Li, H.; Rothberg, L. Colorimetric detection of DNA sequences based on electrostatic interactions with unmodified gold nanoparticles. Proc. Nat. Acad. Sci. USA 2004, 101, 14036-14039. [CrossRef]

54. Koo, K.M.; Sina, A.A.I.; Carrascosa, L.G.; Shiddiky, M.J.A.; Trau, M. DNA-bare gold affinity interactions: Mechanism and applications in biosensing. Anal. Methods 2015, 7, 7042-7054. [CrossRef]

55. Liu, J. Adsorption of DNA onto gold nanoparticles and graphene oxide: Surface science and applications. Phys. Chem. Chem. Phys. 2012, 14, 10485-10496. [CrossRef]

56. Kimura-Suda, H.; Petrovykh, D.Y.; Tarlov, M.J.; Whitman, L.J. Base-dependent competitive adsorption of single-stranded DNA on gold. J. Am. Chem. Soc. 2003, 125, 9014-9015. [CrossRef] 
57. Mirkin, C.A.; Letsinger, R.L.; Mucic, R.C.; Storhoff, J.J. A DNA-based method for rationally assembling nanoparticles into macroscopic materials. Nature 1996, 382, 607-609. [CrossRef]

58. Alivisatos, A.P.; Johnsson, K.P.; Peng, X.; Wilson, T.E.; Loweth, C.J.; Bruchez, M.P.; Schultz, P.G. Organization of 'nanocrystal molecules' using DNA. Nature 1996, 382, 609-611. [CrossRef] [PubMed]

59. Cederquist, K.B.; Keating, C.D. Curvature effects in DNA: Au nanoparticle conjugates. ACS Nano 2009, 3, 256-260. [CrossRef]

60. Elghanian, R.; Storhoff, J.J.; Mucic, R.C.; Letsinger, R.L.; Mirkin, C.A. Selective colorimetric detection of polynucleotides based on the distance-dependent optical properties of gold nanoparticles. Science 1997, 277, 1078-1081. [CrossRef]

61. Huang, Z.; Liu, B.; Liu, J. Parallel polyadenine duplex formation at low $\mathrm{pH}$ facilitates DNA conjugation onto gold nanoparticles. Langmuir 2016, 32, 11986-11992. [CrossRef]

62. Liu, B.; Liu, J. Freezing-driven DNA adsorption on gold nanoparticles: Tolerating extremely low salt concentration but requiring high DNA concentration. Langmuir 2019, 35, 6476-6482. [CrossRef]

63. Liu, B.; Liu, J. Freezing directed construction of bio/nano interfaces: Reagentless conjugation, denser spherical nucleic acids, and better nanoflares. J. Am. Chem. Soc. 2017, 139, 9471-9474. [CrossRef]

64. Zhao, W.; Brook, M.A.; Li, Y. Design of Gold Nanoparticle-Based Colorimetric Biosensing Assays. ChemBioChem 2008, 9, 2363-2371. [CrossRef]

65. Sciortino, F.; Zhang, Y.; Gang, O.; Kumar, S.K. Combinatorial-entropy-driven aggregation in DNA-grafted nanoparticles. ACS Nano 2020, 14, 5628-5635. [CrossRef]

66. Wang, G.; Bu, T.; Zako, T.; Watanabe-Tamaki, R.; Tanaka, T.; Maeda, M. Dark field microscopic analysis of discrete Au nanostructures: Understanding the correlation of scattering with stoichiometry. Chem. Phys. Lett. 2017, 684, 310-315. [CrossRef]

67. Wang, G.; Akiyama, Y.; Shiraishi, S.; Kanayama, N.; Takarada, T.; Maeda, M. Cross-linking versus non-cross-linking aggregation of gold nanoparticles induced by DNA hybridization: A comparison of the rapidity of solution color change. Bioconjug. Chem. 2017, 28, 270-277. [CrossRef]

68. Zanoli, L.M.; D'Agata, R.; Spoto, G. Functionalized gold nanoparticles for ultrasensitive DNA detection. Anal. Bioanal. Chem. 2012, 402, 1759-1771. [CrossRef]

69. Xia, F.; Zuo, X.; Yang, R.; Xiao, Y.; Kang, D.; Vallée-Bélisle, A.; Gong, X.; Yuen, J.D.; Hsu, B.B.Y.; Heeger, A.J.; et al. Colorimetric detection of DNA, small molecules, proteins, and ions using unmodified gold nanoparticles and conjugated polyelectrolytes. Proc. Nat. Acad. Sci. USA 2010, 107, 10837-10841. [CrossRef] [PubMed]

70. Zhao, W.; Chiuman, W.; Lam, J.C.F.; McManus, S.A.; Chen, W.; Cui, Y.; Pelton, R.; Brook, M.A.; Li, Y. DNA aptamer folding on gold nanoparticles: From colloid chemistry to biosensors. J. Am. Chem. Soc. 2008, 130, 3610-3618. [CrossRef]

71. Fujita, M.; Katafuchi, Y.; Ito, K.; Kanayama, N.; Takarada, T.; Maeda, M. Structural study on gold nanoparticle functionalized with DNA and its non-cross-linking aggregation. J. Colloid Interface Sci. 2012, 368, 629-635. [CrossRef] [PubMed]

72. Sato, K.; Hosokawa, K.; Maeda, M. Rapid aggregation of gold nanoparticles induced by non-cross-linking DNA hybridization. J. Am. Chem. Soc. 2003, 125, 8102-8103. [CrossRef]

73. Akiyama, Y.; Shikagawa, H.; Kanayama, N.; Takarada, T.; Maeda, M. DNA dangling-end-induced colloidal stabilization of gold nanoparticles for colorimetric single-nucleotide polymorphism genotyping. Chem. Eur. J. 2014, 20, 17420-17425. [CrossRef]

74. Sato, K.; Hosokawa, K.; Maeda, M. Characterizing the non-crosslinked aggregation of DNA-modified gold nanoparticles: Effects of DNA length and terminal base pair. Analyst 2019, 144, 5580-5588. [CrossRef]

75. Lee, J.; Huh, J.-H.; Lee, S. DNA base pair stacking crystallization of gold colloids. Langmuir 2020, 36, 5118-5125. [CrossRef] [PubMed]

76. Kanayama, N.; Takarada, T.; Fujita, M.; Maeda, M. DNA terminal breathing regulated by metal ions for colloidal logic gates. Chem. Eur. J. 2013, 19, 10794-10798. [CrossRef]

77. Kanayama, N.; Takarada, T.; Maeda, M. Rapid naked-eye detection of mercury ions based on non-crosslinking aggregation of double-stranded DNA-carrying gold nanoparticles. Chem. Commun. 2011, 47, 2077-2079. [CrossRef]

78. Gong, L.; Du, B.; Pan, L.; Liu, Q.; Yang, K.; Wang, W.; Zhao, H.; Wu, L.; He, Y. Colorimetric aggregation assay for arsenic (III) using gold nanoparticles. Microchim. Acta 2017, 184, 1185-1190. [CrossRef] 
79. Lee, J.-S.; Stoeva, S.I.; Mirkin, C.A. DNA-induced size-selective separation of mixtures of gold nanoparticles. J. Am. Chem. Soc. 2006, 128, 8899-8903. [CrossRef]

80. Miyake, Y.; Togashi, H.; Tashiro, M.; Yamaguchi, H.; Oda, S.; Kudo, M.; Tanaka, Y.; Kondo, Y.; Sawa, R.; Fujimoto, T. MercuryII-mediated formation of thymine- HgII- thymine base pairs in DNA duplexes. J. Am. Chem. Soc. 2006, 128, 2172-2173. [CrossRef]

81. Deng, L.; Li, Y.; Yan, X.; Xiao, J.; Ma, C.; Zheng, J.; Liu, S.; Yang, R. Ultrasensitive and highly selective detection of bioaccumulation of methyl-mercury in fish samples via $\mathrm{Ag}^{0} / \mathrm{Hg}^{0}$ Amalgamation. Anal. Chem. 2015, 87, 2452-2458. [CrossRef] [PubMed]

82. Mergler, D.; Anderson, H.A.; Chan, L.H.M.; Mahaffey, K.R.; Murray, M.; Sakamoto, M.; Stern, A.H. Methylmercury exposure and health effects in humans: A worldwide concern. AMBIO 2007, 36, 3-11. [CrossRef]

83. Aulsebrook, M.L.; Watkins, E.; Grace, M.R.; Graham, B.; Tuck, K.L. Modified gold nanoparticles for the temperature-dependent colorimetric detection of mercury and methylmercury. ChemistrySelect 2018, 3, 2088-2091. [CrossRef]

84. Lee, J.S.; Han, M.S.; Mirkin, C.A. Colorimetric detection of mercuric ion $\left(\mathrm{Hg}^{2+}\right)$ in aqueous media using DNA-functionalized gold nanoparticles. Angew. Chem. Int. Ed. 2007, 46, 4093-4096. [CrossRef]

85. Xue, X.; Wang, F.; Liu, X. One-step, room temperature, colorimetric detection of mercury $\left(\mathrm{Hg}^{2+}\right) \mathrm{using}$ DNA/nanoparticle conjugates. J. Am. Chem. Soc. 2008, 130, 3244-3245. [CrossRef]

86. Zhang, L.; Wang, Z.-X.; Liang, R.-P.; Qiu, J.-D. Easy design of colorimetric logic gates based on nonnatural base pairing and controlled assembly of gold nanoparticles. Langmuir 2013, 29, 8929-8935. [CrossRef]

87. Sugiyama, H.; Adachi, N.; Kawauchi, S.; Kozasa, T.; Katayama, T.; Torigoe, H.; Ono, A.; Tamura, Y. Computational evaluation of the specific interaction between cation and mismatch base pair. Nucleic Acids Symp. Ser. 2005, 49, 215-216. [CrossRef]

88. Xi, H.; Cui, M.; Li, W.; Chen, Z. Colorimetric detection of $\mathrm{Ag}^{+}$based on $\mathrm{CAg}^{+} \mathrm{C}$ binding as a bridge between gold nanoparticles. Sens. Actuators B Chem. 2017, 250, 641-646. [CrossRef]

89. Liu, J.; Lu, Y. A colorimetric lead biosensor using DNAzyme-directed assembly of gold nanoparticles. J. Am. Chem. Soc. 2003, 125, 6642-6643. [CrossRef]

90. Liu, J.; Lu, Y. Accelerated color change of gold nanoparticles assembled by DNAzymes for simple and fast colorimetric Pb2+ detection. J. Am. Chem. Soc. 2004, 126, 12298-12305. [CrossRef]

91. Wang, H.-B.; Ma, L.-H.; Fang, B.-Y.; Zhao, Y.-D.; Hu, X.-B. Graphene oxide-assisted Au nanoparticle strip biosensor based on GR-5 DNAzyme for rapid lead ion detection. Colloids Surf. B 2018, 169, 305-312. [CrossRef] [PubMed]

92. Nigam, A.; Bhati, V.S.; Bhat, T.N.; Dolmanan, S.B.; Tripathy, S.; Kumar, M. Sensitive and selective setection of $\mathrm{Pb}^{2+}$ ions using 2,5-dimercapto-1,3,4-thiadiazole functionalized AlGaN/GaN high electron mobility transistor. IEEE Electron. Device Lett. 2019, 40, 1976-1979. [CrossRef]

93. Yang, D.; Liu, X.; Zhou, Y.; Luo, L.; Zhang, J.; Huang, A.; Mao, Q.; Chen, X.; Tang, L. Aptamer-based biosensors for detection of lead(ii) ion: A review. Anal. Methods 2017, 9, 1976-1990. [CrossRef]

94. Wu, Y.; Zhan, S.; Wang, F.; He, L.; Zhi, W.; Zhou, P. Cationic polymers and aptamers mediated aggregation of gold nanoparticles for the colorimetric detection of arsenic (III) in aqueous solution. Chem. Commun. 2012, 48, 4459-4461. [CrossRef]

95. Liu, C.-W.; Hsieh, Y.-T.; Huang, C.-C.; Lin, Z.-H.; Chang, H.-T. Detection of mercury (II) based on Hg 2+-DNA complexes inducing the aggregation of gold nanoparticles. Chem. Commun. 2008, 2242-2244. [CrossRef]

96. Zhou, M.; Lin, T.; Gan, X. Colorimetric aggregation assay for silver (I) based on the use of aptamer modified gold nanoparticles and C-Ag (I)-C interaction. Microchim. Acta 2017, 184, 4671-4677. [CrossRef]

97. Chen, G.-H.; Chen, W.-Y.; Yen, Y.-C.; Wang, C.-W.; Chang, H.-T.; Chen, C.-F. Detection of mercury (II) ions using colorimetric gold nanoparticles on paper-based analytical devices. Anal. Chem. 2014, 86, 6843-6849. [CrossRef]

98. Kim, M.; Um, H.-J.; Bang, S.; Lee, S.-H.; Oh, S.-J.; Han, J.-H.; Kim, K.-W.; Min, J.; Kim, Y.-H. Arsenic removal from Vietnamese groundwater using the arsenic-binding DNA aptamer. Environ. Sci. Technol. 2009, 43, 9335-9340. [CrossRef]

99. Zhan, S.; Yu, M.; Lv, J.; Wang, L.; Zhou, P. Colorimetric detection of trace arsenic (III) in aqueous solution using arsenic aptamer and gold nanoparticles. Aust. J. Chem. 2014, 67, 813-818. 
100. Kempahanumakkagari, S.; Deep, A.; Kim, K.-H.; Kumar Kailasa, S.; Yoon, H.-O. Nanomaterial-based electrochemical sensors for arsenic-A review. Biosens. Bioelectron. 2017, 95, 106-116. [CrossRef] [PubMed]

101. Liang, R.P.; Wang, Z.X.; Zhang, L.; Qiu, J.D. Label-free colorimetric detection of arsenite utilizing G-/T-rich oligonucleotides and unmodified Au nanoparticles. Chem. Eur. J. 2013, 19, 5029-5033. [CrossRef]

102. Liu, R.; Chen, Z.; Wang, Y.; Cui, Y.; Zhu, H.; Huang, P.; Li, W.; Zhao, Y.; Tao, Y.; Gao, X. Nanoprobes: Quantitatively detecting the femtogram level of arsenite ions in live cells. ACS Nano 2011, 5, 5560-5565. [CrossRef]

103. Wu, Y.; Zhan, S.; Wang, L.; Zhou, P. Selection of a DNA aptamer for cadmium detection based on cationic polymer mediated aggregation of gold nanoparticles. Analyst 2014, 139, 1550-1561. [CrossRef]

104. Wei, H.; Li, B.; Li, J.; Dong, S.; Wang, E. DNAzyme-based colorimetric sensing of lead (Pb2+) using unmodified gold nanoparticle probes. Nanotechnology 2008, 19, 095501. [CrossRef]

105. Wang, Z.; Lee, J.H.; Lu, Y. Label-free colorimetric detection of lead ions with a nanomolar detection limit and tunable dynamic range by using gold nanoparticles and DNAzyme. Adv. Mater. 2008, 20, 3263-3267. [CrossRef]

106. Memon, A.G.; Zhou, X.; Xing, Y.; Wang, R.; Liu, L.; Khan, M.; He, M. Label-free colorimetric nanosensor with improved sensitivity for $\mathrm{Pb} 2+$ in water by using a truncated 8-17 DNAzyme. Front. Environ. Sci. Eng. 2019, 13, 12. [CrossRef]

107. Liu, C.-W.; Huang, C.-C.; Chang, H.-T. Control over surface DNA density on gold nanoparticles allows selective and sensitive detection of mercury (II). Langmuir 2008, 24, 8346-8350. [CrossRef]

108. Wang, L.; Liu, F.; Sui, N.; Liu, M.; William, W.Y. A colorimetric assay for $\mathrm{Hg}$ (II) based on the use of a magnetic aptamer and a hybridization chain reaction. Microchim. Acta 2016, 183, 2855-2860. [CrossRef]

109. Rohs, R.; Sklenar, H.; Lavery, R.; Röder, B. Methylene blue binding to DNA with alternating GC base sequence: A modeling study. J. Am. Chem. Soc. 2000, 122, 2860-2866. [CrossRef]

110. Diao, W.; Wang, G.; Wang, L.; Zhang, L.; Ding, S.; Takarada, T.; Maeda, M.; Liang, X. Opposite effects of flexible single-stranded DNA regions and rigid loops in DNAzyme on colloidal nanoparticle stability for "turn-on" plasmonic detection of lead ions. ACS Appl. Bio Mater. 2020, 3, 7003-7010. [CrossRef]

111. Deshmukh, M.A.; Celiesiute, R.; Ramanaviciene, A.; Shirsat, M.D.; Ramanavicius, A. EDTA_PANI/SWCNTs nanocomposite modified electrode for electrochemical determination of copper (II), lead (II) and mercury (II) ions. Electrochim. Acta 2018, 259, 930-938. [CrossRef]

112. Zhang, L.; Zhao, C.; Zhang, Y.; Wang, L.; Wang, G.; Kanayama, N.; Takarada, T.; Maeda, M.; Liang, X. Chemically fueled plasmon switching of gold nanorods by single-base pairing of surface-grafted DNA. Langmuir 2019, 35, 11710-11716. [CrossRef]

113. Labatzke, T.; Schlemmer, G. Ultratrace determination of mercury in water following EN and EPA standards using atomic fluorescence spectrometry. Anal. Bioanal. Chem. 2004, 378, 1075-1082. [CrossRef] [PubMed]

114. Wang, F.; Cheng, S.; Bao, Z.; Wang, J. Anisotropic overgrowth of metal heterostructures induced by a site-selective silica coating. Angew. Chem. Int. Ed. 2013, 52, 10344-10348. [CrossRef]

115. Carbó-Argibay, E.; Rodríguez-González, B.; Gómez-Graña, S.; Guerrero-Martínez, A.; Pastoriza-Santos, I.; Pérez-Juste, J.; Liz-Marzán, L.M. The crystalline structure of gold nanorods revisited: Evidence for higher-index lateral facets. Angew. Chem. Int. Ed. 2010, 49, 9397-9400. [CrossRef]

116. Chang, C.-C.; Wang, G.; Takarada, T.; Maeda, M. Target-recycling-amplified colorimetric detection of pollen allergen using non-cross-linking aggregation of DNA-modified gold nanoparticles. ACS Sens. 2019, 4, 363-369. [CrossRef] [PubMed]

117. Akiyama, Y.; Wang, G.; Shiraishi, S.; Kanayama, N.; Takarada, T.; Maeda, M. Rapid naked-eye discrimination of cytochrome $\mathrm{P} 450$ genetic polymorphism through non-crosslinking aggregation of DNA-functionalized gold nanoparticles. ChemistryOpen 2016, 5, 508-512. [CrossRef]

118. Wang, L.; Wang, G.; Shi, Y.; Zhang, L.; An, R.; Takarada, T.; Maeda, M.; Liang, X. Accelerated non-crosslinking assembly of DNA-functionalized nanoparticles in alcoholic solvents: For application in the identification of clear liquors. Analyst 2020, 145, 3229-3235. [CrossRef]

119. Wang, G.; Yu, L.; Akiyama, Y.; Takarada, T.; Maeda, M. Reversible shrinkage of DNA-functionalized gold nanoparticle assemblies revealed by surface plasmon resonance. Biotechnol. J. 2018, 13, 1800090. [CrossRef] 
120. Wu, T.-H.; Chang, C.-C.; Vaillant, J.; Bruyant, A.; Lin, C.-W. DNA biosensor combining single-wavelength colorimetry and a digital lock-in amplifier within a smartphone. Lab Chip 2016, 16, 4527-4533. [CrossRef]

121. Li, Y.; Chen, Y.; Yu, H.; Tian, L.; Wang, Z. Portable and smart devices for monitoring heavy metal ions integrated with nanomaterials. TrAC Trends Anal. Chem. 2018, 98, 190-200. [CrossRef]

Publisher's Note: MDPI stays neutral with regard to jurisdictional claims in published maps and institutional affiliations.

(C) 2020 by the authors. Licensee MDPI, Basel, Switzerland. This article is an open access article distributed under the terms and conditions of the Creative Commons Attribution (CC BY) license (http://creativecommons.org/licenses/by/4.0/). 